\title{
The Relationship of Entrepreneurial Activity and the Level of Institutional and Market-Based Infrastructure of Business
}

\author{
Palyakin Roman Borisovich \\ Post-graduate student of the Department for Marketing, Commerce and Entrepreneurship, \\ Kazan (Volga Region) Federal University
}

Tarkaeva Natalia Aleksandrovna

Chamber of commerce and industry of the Republic of Tatarstan, member of the board

Doi:10.5901/mjss.2014.v5n18p305

\begin{abstract}
This article provides the analysis of the relationship between the development of business infrastructure and the level of business activity in the Russian Federation. The classification of parameters of the region infrastructure development has been suggested. The principles of structural and functional models for infrastructure support are defined. The implementation of the structurally functional model of the Republic of Tatarstan is proposed.
\end{abstract}

Keywords: entrepreneurship, the region's economy, institutional and market-based infrastructure, small businesses infrastructure support.

\section{Introduction}

As evidenced by the analysis of global experience in establishing favorable conditions for the development of small business, the most effective tools of regulation in the long term are investments in infrastructure, because its level of development is one of the main incentives to encourage entrepreneurial activity at early stages of a business entity lifecycle [1].

It should also be mentioned that a key element in the national economy is economic activity of regions as state and regional development programs for small and medium businesses are implemented at the mesolevel.

These statements allow us to evaluate the institutional and market-based business infrastructure in the regions of Russia by certain indicators that reflect the impact of state and regional activities in the context of entrepreneurship. Observations were made on key parameters that reflect the essence of institutional and market-based infrastructure of business.

The model of the relationship between entrepreneurial activity and infrastructure support is based on the definition of the set of parameters which directly influence the formation and development of small businesses. These parameters have been analyzed by such Russian scientists as Kalenskaya N.V., Panasyuk, M.V., Bagautdinova, N.G., Safiullin, L.N., [1-12] and others.

Our study is mainly focused on the development of institutional and market infrastructure of business activities, which is subject to changes in both external and internal factors. In our opinion the parameters of rate of taxes and tariffs are not sufficiently dynamic to show the real picture of infrastructural support for entrepreneurship, as statistic data indicate rather weak connection between amount of business structures and lending rates and taxation [5].

Thus, in order to improve the parameters' classification of entrepreneurship infrastructural support and taking into consideration the institutional and market components of business infrastructure, we propose the classification of business infrastructure parameters. The classification is based on principles of coordination of infrastructure elements' activity, as well as the degree of participation (involvement) in the process of entrepreneurship development.

The parameters are classified by two basic branches of business infrastructure, and each of them includes several factors, i.e. "indicators" of infrastructural support:

1. Institutional infrastructure of entrepreneurship:

- the number of state and regional budget funds for business development (government subsidies, the implementation of small business supporting programs); 
- the number of contracts for supply of goods for sale and municipal needs;

- the number of newly established enterprises with the support of government institutions (institutional renewal of business).

2. Market infrastructure of entrepreneurship:

- $\quad$ the average number of employees in business structures (workforce providing);

- volume of loans for business development at the regional level (by MSP bank and partner-banks).

The necessity to determine the connection between the development of entrepreneurial structures and the level of business-support infrastructure functioning provides the construction of economic and mathematical model of multiple linear regression.

\section{The Results Obtained}

We based our study of the federal districts' business infrastructure on the data on small business in Russia in 2010-2013, which is presented in the statistic information databases, and determined the dynamics of infrastructure development (Table 1)

Table 1. Dynamics of infrastructural support parameters for small business (average by federal districts) for the period from 2010 to 2013.

\begin{tabular}{|c|c|c|c|c|}
\hline $\begin{array}{l}\text { Number of newly } \\
\text { established enterprises, } \\
\text { thousand units }\end{array}$ & $\begin{array}{l}\text { The number of contracts for } \\
\text { supply of goods for the state } \\
\text { needs, thousand units }\end{array}$ & $\begin{array}{l}\text { Funds for the implementation } \\
\text { of SB support programs, bln } \\
\text { rubles. }\end{array}$ & $\begin{array}{l}\text { Average number of } \\
\text { employees, million } \\
\text { people. }\end{array}$ & $\begin{array}{l}\text { The volume of loans for } \\
\text { SB development, bln } \\
\text { rubles. }\end{array}$ \\
\hline 19,58 & 16,16 & 3,16 & 1,7 & 0,37 \\
\hline 22,06 & 14,25 & 3,12 & 1,4 & 0,7 \\
\hline 24,26 & 14,7 & 3,6 & 1,45 & 0,8 \\
\hline 26,69 & 13,58 & 3,3 & 1,44 & 1,15 \\
\hline
\end{tabular}

Analyzing the data, one can state that the development of infrastructure for entrepreneurship support is gradual and on the whole has a positive trend. The exceptions are the factors that characterize the degree of state participation in the development of business structures, namely providing contracts for goods' supply for the state (or municipal) needs and the amount of funds allocated to small business development programs in the regions. However, the evolution of the parameters of infrastructural support occurs systematically, although it has a tendency to decrease.

Table 2 shows the parameters that estimate the quality of the relationship between entrepreneurial activity and indicators of business infrastructure development.

Then we define a linear dependence of entrepreneurial activity on the level of infrastructure development (Formula (1)). The linear dependence of the number of SB entities on each factor separately is reflected in formulas (2) - (6).

Table 2. The correlation-regressive analysis of the relationship between business activity and infrastructure development in the RF federal districts in 2010-2013.

\begin{tabular}{|l|c|c|c|c|c|}
\hline Parameter name & & $\begin{array}{c}\text { Value of pair } \\
\text { correlation }\end{array}$ & $\begin{array}{c}\text { Nature of relationship } \\
\text { with the dependent } \\
\text { variable }\end{array}$ & $\begin{array}{c}\text { Elasticity of } \\
\text { parameter (rel. to } \\
\text { dependent variable) }\end{array}$ & $\begin{array}{c}\text { Significance of } \\
\text { oefficient } \\
\text { (determination) }\end{array}$ \\
\hline Number of SB subjects, thousand units & $y$ & - & - & - & 0,9978 \\
\hline $\begin{array}{l}\text { Average number of SB employees, thousand } \\
\text { people }\end{array}$ & $x 1$ & 0,9339 & straight, very close & 0,2563 & 0,9917 \\
\hline $\begin{array}{l}\text { The number of newly established SB } \\
\text { enterprises, thousand units }\end{array}$ & $x 2$ & 0,9876 & straight, very close & 0,6821 & 0,9560 \\
\hline $\begin{array}{l}\text { State budge expenses for the development of } \\
\text { entrepreneurship, bln. rubles }\end{array}$ & $x 3$ & 0,7945 & straight, close & $-0,0243$ & 0,9971 \\
\hline $\begin{array}{l}\text { The number of contracts for the supply of } \\
\text { goods for state needs, thousand units }\end{array}$ & $x 4$ & 0,6881 & straight, not close & $-0,0503$ & 0,9979 \\
\hline $\begin{array}{l}\text { The volume of loans for the development of } \\
\text { SB, bln. rubles }\end{array}$ & $x 5$ & 0,8771 & straight, close & 0,0816 & 0,9954 \\
\hline
\end{tabular}


Analyzing the relationship between the number of SB enterprises and certain factors of infrastructure development, one can come to conclusion about the positive impact of each factor. But according to the determination coefficients all the factors affect the activity of business organizations differently.

The analyzed factors of infrastructural support explain the level of entrepreneurial activity (by classification parameters) to $87.22 \%$ (headcount), $97.54 \%$ (the number of newly created SB entities), $63.13 \%$ (volume of investments in business development programs), $47.35 \%$ (number of contracts for the supply of goods for municipal purposes) and $76.94 \%$ (volume of loans for SB development) respectively.

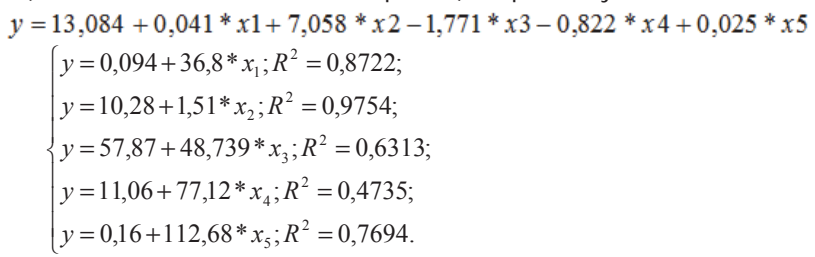

Then in accordance with the analytic hierarchy process (AHP) we evaluated the ponderability (weightiness) of each element in the system of infrastructure support. Further on intermediate and normalized scores for each indicator of infrastructural support average in Russia for the period of 2010-2013 were identified on the basis of alternative estimation method for quantitative criteria using Harrington scale (more information in I.I. Ismaghilov's paper [6]). (Table 3).

The greatest change in the normalized estimates is observed in staffing options (sharp decline in 2011 compared to 2010), as well as the opposite change of the parameter of financial-and-credit entrepreneurship support (sharp increase in 2011 compared to 2010). And as the staffing is of high ponderability (weightiness) in the model (compared to the financial and credit support), the evaluation of infrastructure development is reduced in 2011. But later on there is a regular increase in the model estimations in years.

Table 3. Estimation of parameters of entrepreneurship infrastructural support in Russia in 2010-2013, (by Harrington scale)

\begin{tabular}{|c|c|c|c|c|c|c|c|c|c|c|}
\hline \multirow{2}{*}{ Group feature } & \multirow{2}{*}{ No } & \multicolumn{4}{|c|}{ Years } & \multirow{2}{*}{$\begin{array}{c}\text { Ponderabilityl } \\
\text { Weightiness factor } a=\end{array}$} & \multicolumn{4}{|c|}{$\begin{array}{l}\text { Standardized/ Normalized estimates } \\
\text { (years) }\end{array}$} \\
\hline & & 2010 & 2011 & 2012 & 2013 & & 2010 & 2011 & 2012 & 2013 \\
\hline Staffing, thousand people & 1 & 1716,4 & 1434,9 & 1453,65 & 1437,1 & 0,266 & 0,9642 & 0,4774 & 0,5133 & 0,4817 \\
\hline $\begin{array}{l}\text { Institutional renewal, } \\
\text { thousand units }\end{array}$ & 2 & 19,583 & 22,065 & 24,260 & 26,689 & 0,2963 & 0,4227 & 0,6340 & 0,7655 & 0,9825 \\
\hline $\begin{array}{l}\text { Budget of regional SB } \\
\text { development programs, billion } \\
\text { rubles. }\end{array}$ & 3 & 3,157 & 3,124 & 3,596 & 3,310 & 0,1711 & 0,7856 & 0,7738 & 0,9974 & 0,9375 \\
\hline $\begin{array}{l}\text { State market support } \\
\text { contracts for goods' supply, } \\
\text { thousand units }\end{array}$ & 4 & 16,162 & 14,257 & 14,705 & 13,584 & 0,0901 & 0,9942 & 0,7656 & 0,8023 & 0,7041 \\
\hline $\begin{array}{l}\text { SB financial and credit } \\
\text { support, billion rubles. }\end{array}$ & 5 & 376,85 & 756,56 & 867,5 & 1157,62 & 0,1765 & 0,1331 & 0,5785 & 0,6963 & 0,9936 \\
\hline FINAL ASSESSMENTS (includi & ling $f$ & eature $p$ & onderab & jility/ weig & ghtiness) & & 0,6292 & 0,6183 & 0,7292 & 0,818 \\
\hline
\end{tabular}

One can also mention that these estimates may serve as one of the efficiency criteria in the research of small business infrastructure development, because the overall (total) score tends to 1 . Therefore, stating that the current level of infrastructure reflects its effectiveness insofar as the estimate for this model is close to 1 , can be a logical conclusion from the model. Respectively, the highest efficiency of business infrastructure (average in federal districts) reflects the estimate for the year of $2013(0,818)$.

Interaction of entrepreneurial activity in the region and infrastructure support implies the introduction of the structurally functional model of infrastructure support, in which infrastructural elements of entrepreneurship support interact at the regional level.

According to Kalenskaya N.V., the peculiarity of the regional infrastructure arrangement is the professional orientation to the requirements of the region and the sector [7, p.80]. This conclusion, in our opinion, is fundamental in constructing a strategic framework for infrastructural support of entrepreneurship. 
The construction of structurally functional model provides a number of principles for the functioning of institutional and market-based entrepreneurship infrastructure. The list of the principles for forming structurally functional model of infrastructural support for innovative development of industrial clusters, which we used as a basis, is given in $\mathrm{N}$. Kalenskaya's work [35, p. 83]. However, based on the features of forming infrastructure for regional business development, as well as features of the institutional and market-based infrastructure of business in the region, this list has been supplemented, and new principles have been defined. The principles of the infrastructure support system evolution, adapted to socio-economic development of entrepreneurship in the region, are the following:

- systemic, purpose-oriented and coordinated main elements of the institutional and market infrastructure are the basis for socio-economic development of the region;

- the necessity to create a single information space, which combines regional centers of business support, institutions of professional business capacity, different types of small businesses support institutions;

- consideration of current business level provided with credit-financial, technical, information resources and the specific institutional and market-based infrastructure in general in accordance with various aspects of socioeconomic development of the region;

- the existing implementation based on information support of business by regional entities of institutional infrastructure aimed at the information transparency of entrepreneurial activity;

- the effect of structurally functional model of infrastructure support is targeted the satisfaction of business structures with infrastructure elements' services for building a unified strategy for infrastructure support and growing entrepreneurial activity of the regional economy;

- interaction of elements in the model of infrastructure support is a compromise, whereby resources of infrastructure elements are distributed in accordance with the needs of business organizations within the regional economy.

The implementation of this model lets us not only organize the system of small businesses infrastructure support in the region (taking into account features of socio-economic development), but also correct elements' forming of infrastructure support. In turn, the invariance of the involved resources and determination of resource potential allows us to define different ways of building business infrastructure and provide opportunities for optimizing the model of entrepreneurship infrastructural support in general.

\section{Conclusions}

The basis for the development of entrepreneurship regional economy is the construction of an effective system of business infrastructure. Parameters for analyzing the development of the regional business infrastructure are the elements of institutional and market-based infrastructure in the region: the number of small businesses created, the level of credit-financial and budgetary support, small business human resources and market state support of business (on contract basis).

The level of entrepreneurial activity of the regional economy strongly depends on the development of institutional and market-based business infrastructure, as in these two types of infrastructure the conditions for small business support are formed via realization of entrepreneurship support through institutional and market-based facilitating instruments; herewith entrepreneurs and regional authorities collaborate as partners.

The construction of structurally functional model of infrastructure support takes place in order to make management decisions in the sphere of business infrastructure. Invariance and the degree of elements' involvement of infrastructure resources are explained by heterogeneity (asymmetry) of the institutional sphere development in the regions; wherein regional imbalances in socio-economic development can be eliminated via strategic tools of business infrastructure management.

Thus, the analysis of the relationship of entrepreneurial activity in the region and the development of business infrastructure allows us, on the one hand, to evaluate the effectiveness of infrastructural support of small businesses, and on the other hand, to identify strategic directions for improving the competitiveness of the regional economy due to the growth of entrepreneurial activity. 


\section{References}

Gafurov I.R., Bagautdinova N.G., Panasyuk M.V. Analysis of Strategic Perspectives of Competitiveness of Kazan // Recent Researches in Urban Sustainability, Architecture and Structures. Proceedings of the 2nd International Conference on Sustainable Cities, Urban Sustainability and Transportation (SCUST'13). Baltimore, MD, USA, September 17-19, 2013. - Baltimore: WSEAS Press. - 2013. - pp. $37-44$.

Bagautdinova, N., Gafurov, I., Kalenskaya, N., Novenkova, A. The regional development strategy based on territorial marketing (The Case of Russia) // World Applied Sciences Journal, 18(Issue SPL.ISSUE. 18), 2012, 179-184.

Panasyuk, M.V., Bagautdinova, N.G., Safiullin, L.N., Novenkova, A.Z. Territorial approach to solving the region strategic management problems // World Applied Sciences Journal, 27(13), 2013, 149-153.

Panasyuk, M.V., Safiullin, L.N., Pryadko, I.A., Anopchenko, T.Y. Classification of large and socially important enterprises of the region by the levels of their economic solvency // World Applied Sciences Journal, 27(13), 2013, 140-144.

Safiullin, M.R., Elshin, L.A., Prygunova, M.I., Galyavov, A.A. (2013). Complex Analysis of Prospects of the Volga Federal District Regions Development: Methodology and Practice. World Applied Sciences Journal 27, 4, 508-511.

Fakhrutdinova, E., Kirshin, I., Kolesnikova, J., Salyakhov, E. The influence of cross-country technological transfer on economic profit formation// Middle East Journal of Scientific Research. Volume 17, Issue 12, 2013, Pages 1632-1634.

Fakhrutdinova, E., Kolesnikova, J., Kiselkina, O., Khalikov, A. Issues of commercialization of intangible property rights in Russia// World Applied Sciences Journal. Volume 27, Issue 13, 2013, Pages 72-76.

Fakhrutdinova, E., Fakhrutdinova, A., Severyanov, O., Valeev, E. The transformation of educational approaches at the time of social and economical changes// World Applied Sciences Journal.Volume 27, Issue 13, 2013, Pages 15-19.

Fakhrutdinova, E., Safina, L., Shigapova, D., Yagudin, R. Legislative provision of the quality of working life in Russia// World Applied Sciences Journal.Volume 27, Issue 13, 2013, Pages 92-96.

Kirshin I.A., Datsyk A.A., Titov A.V. Forecasting the Dynamics of an Innovative Cycle. - World Applied Sciences Journal (Economics, Management and Finance). - 2013. - №27. - P. 197 - 201.

Glebova I.S., Sadyrtdinov R. and Rodnyansky D. Impact Analysis of Investment Attractiveness of the Republic of Tatarstan on Fixed Investments of its Leading Companies // World Applied Sciences Journal 26 (7): 911-916, 2013.

Glebova I.S., Khabibrakhmanova R. and Yasnitskaya Y. The Analysis of the Impact of the Investment Attractiveness Factors of the Region on the Fixed Capital Investments in the Economy of the Republic of Tatarstan II Middle-East Journal of Scientific Research 17 (10): 1498-1502, 2013.

Palagushkina O.V. Diatoms of modern bottom sediments in Siberian arctic (2012) Contemporary Problems of Ecology (4) , pp. 413-422.

Melnik A.N. The Organization of Russian Power Market in Modern Conditions / A.N. Melnik, O.N. Mustafina // Middle-East Journal of Scientific Research. - 2013. - v. 13 - pp. 91-94.

Novenkova A.Z., Gafurov I.R., Kalenskaya N.V. Marketing of Educational Services: Research on Service Providers Satisfaction /I Procedia Economics and Finance, Volume 5, 2013, Pages 368-376.

Bagautdinova, N., Gafurov, I., Kalenskaya, N., Novenkova, A. The regional development strategy based on territorial marketing (The Case of Russia) // World Applied Sciences Journal, 18(Issue SPL.ISSUE. 18), 2012, 179-184. 
